\title{
Biological and Chemical Basis for the Reclassification of Microbacterium flavum Orla-Jensen as Corynebacterium flavescens nom. nov.
}

\author{
L. BARKSDALE, ${ }^{1}$ M.-A. LANÉLLLE, ${ }^{2}$ M. C. POLLICE, ${ }^{1}$ \\ J. ASSELINEAU, ${ }^{2}$ M. WELBY, ${ }^{2}$ AND M. V. NORGARD ${ }^{3}$ \\ Department of Microbiology, New York University Medical Center, New York, New York 10016 ${ }^{1}$; Centre de \\ Recherche de Biochimie et de Génétique Cellulaires, Centre National de la Recherche Scientifique, 31077 \\ Toulouse Cédex, France ${ }^{2}$; and Department of Cell Biology, Roche Institute of Molecular Biology, Nutley, \\ New Jersey $07110^{3}$
}

On the basis of its biological properties (cell morphology, staining reactions, cellular inclusions, guanine plus cytosine content of deoxyribonucleic acid, degree of deoxyribonucleic acid homology with Corynebacterium diphtheriae strain PW8, and pattern of enzymic capacities) and chemical structures (peptidoglycan type, major cell wall polysaccharide, major phospholipids and glycolipid, as well as characteristic cell wall fatty acids), Microbacterium flavum Orla-Jensen (synonym: Mycobacterium flavum Jensen) is renamed Corynebacterium flavescens nom. nov. The specific epithet "flavum" has been changed to "flavescens" in order to avoid the creation of a later homonym of Corynebacterium flavum Kisskalt and Berend 1918. Strain 8 of Orla-Jensen ( $=$ ATCC $10340=$ NCIB 8707) is herein designated the type strain of $C$. flavescens. An updated description of the organism is given.

Microbacterium flavum Orla-Jensen 1919 (57) has long been recognized as being closely related to the group of microorganisms which comprise the Corynebacterium-Mycobacterium-Nocardia (11) group (38) of bacteria, first on morphological and cultural grounds, and more recently on the basis of cell wall structure $(41,63,65,74)$ guanine plus cytosine $(\mathrm{G}+\mathrm{C})$ content of the deoxyribonucleic acid (DNA) $(20,75)$, and generic lipids (30), and, herein, on the basis of characteristic lipids. We present here a further biological and chemical analysis of the strain herein proposed as the type strain of Microbacterium flavum and propose the transfer of this organism to the genus Corynebacterium.

\section{MATERIALS AND METHODS}

Bacterial strains. $M$. flavum American Type Culture Collection (ATCC) strain 10340 (= National Collection of Industrial Bacteria [NCIB] strain $8707=$ strain number 8 of Orla-Jensen [57]) was the only Microbacterium strain examined. Efforts to obtain other authentic strains of this species (62) failed. Some investigators who had recently worked with strains identified as $M$. flavum reported that their cultures were no longer viable (personal communications from $\mathrm{K}$. Robinson [62] and Malcolm Woodbine, University of Nottingham School of Agriculture, Sutton Bonington, England). The Park-Williams number 8 strain of Corynebacterium diphtheriae (58), which we used as a source of "standard" DNA for the DNA hybridization studies, has recently been described in some detail (44). Other corynebacteria used as controls for various biochemical tests included: $C$. diphtheriae (mitis) strain C7 (14); C. diphtheriae (gravis) strain HF (10); C. pseudodiphtheriticum ATCC 10700; C. xerosis strain 53-K-1 (13); C. minutissimum ATCC 23348; $C$. renale ATCC 19412, NCTC 7449, and strain 8 from R. Yanagawa (34); C. pilosum strain 46 (76); C. cystitidis strains 42 and $47(33,76)$; C. genitalium strains 392-1 and 418-H (29); and Corynebacterium sp. strain 43 (isolated from a case of lepromatous leprosy). Additional control organisms included: $C$. pyogenes strain 637S (13); Brevibacterium vitarumen strain 12143 (45); Brevibacterium liquefaciens ATCC 14929; Bacterionema matruchotii ATCC 14266 and 14265; Escherichia coli (a methyl red-positive, Voges-Proskauernegative strain); Enterobacter aerogenes (a methyl red-negative, Voges-Proskauer-positive strain); and Staphylococcus aureus strain Copenhagen (an alkaline-phosphatase-positive strain).

Cultivation of bacteria. Actively growing cultures were employed for all tests. Unless indicated otherwise, seed inoculum was prepared in brain heart infusion (BHI) broth (Difco Laboratories) or on chocolate agar. (A $500-\mathrm{ml}$ volume of neopeptone infusion agar [3] was melted in an autoclave $\left[15 \mathrm{lb} / \mathrm{in}^{2}, 15 \mathrm{~min}\right]$ and then cooled to 75 to $80^{\circ} \mathrm{C}$. To this was added $25 \mathrm{ml}$ of sterile horse blood. With further gentle mixing, the blood agar was placed again into the water bath and was maintained at 75 to $80^{\circ} \mathrm{C}$ for 3 to $5 \mathrm{~min}$. The blood agar was again mixed by turning the bottle over until a chocolate color developed. This was then cooled to around $55^{\circ} \mathrm{C}$. Sterile horse serum [ $\left.35 \mathrm{ml}\right]$ was added and mixed well.)

For the preparation of DNA for homology studies and for assessing the G+C content of the DNA, cultures were grown from small inocula in a broth containing equal amounts of PGT medium supplemented 
with galactose or maltose (35) and neopeptone infusion broth plus polyoxyethylene sorbitan monooleate as Tween $80\left(0.05 \%\right.$, vol/vol). Incubation was at $30^{\circ} \mathrm{C}$ in a New Brunswick shaking water bath (200 to $240 \mathrm{rpm}$ ). Once the optical density of the culture reached 3.0 as measured with a Bausch and Lomb Junior spectrophotometer at $590 \mathrm{~nm}$, sterile glycine was added to yield a final concentration of $0.2 \mathrm{M}$, and incubation continued until the optical density reached 6.0. Cells were harvested at $12,000 \mathrm{rpm}$ and frozen until needed for lysing and extraction of their DNA (54).

Biological and biochemical tests. (i) Detection of polyphosphate (metachromatic) granules. Bacteria were seeded on slants of inspissated serum (Loeffler medium [Baltimore Biological Laboratory] containing an additional $2.5 \mathrm{~g}$ of $\mathrm{K}_{2} \mathrm{HPO}_{4}$ per liter) and incubated for $24 \mathrm{~h}$. Smears were dried, heat fixed, and stained for $15 \mathrm{~min}$ with alkaline methylene blue $(0.3 \mathrm{~g}$ of methylene blue chloride in $30 \mathrm{ml}$ of absolute ethanol was, at $24 \mathrm{~h}$ after mixing, combined with $99 \mathrm{ml}$ of distilled water containing $1 \%[\mathrm{wt} / \mathrm{vol}] \mathrm{KOH}$ and passed through a $0.45-\mu \mathrm{m}$ membrane filter [Nalgene Labware Div., Nalge/Sybron Corp.]). The metachromatic granules, consisting principally of polymetaphosphate $(11,28,32)$, appear as pinkish- to reddishpurple inclusions against a blue background.

(ii) Reduction of potassium tellurite. Within 24 $\mathrm{h}$ of preparation, fresh agar plates of Tinsdale medium $(0.03 \%$ potassium tellurite [69]), as modified by Moore and Parsons (55), were streaked and incubated at $30^{\circ} \mathrm{C}$ until visible colonies appeared. Those colonies which reduced the tellurite appeared metallic gray to glistening black. This medium is also useful for demonstrating the production of $\mathrm{H}_{2} \mathrm{~S}$.

(iii) Catalase. Cultures taken from visible growth on chocolate agar by means of a sterile loop were smeared on clean glass slides. A drop of $\mathrm{H}_{2} \mathrm{O}_{2}(3 \%$, vol/ vol, in distilled water) was added. The vigorous evolution of bubbles was considered indicative of catalase activity.

(iv) Detection of glucan phosphorylase ( $\alpha-1,4-$ glucan:orthophosphate glucosyl transferase) activity. The general procedure of Arden and Barksdale (4) was employed for detecting the synthesis of iodinophilic, starch-like material from glucose 1-phosphate except that only liquid cultures were used. After incubation at $30^{\circ} \mathrm{C}$ in an atmosphere of $10 \% \mathrm{CO}_{2}-\mathrm{N}_{2}$, iodine was added to each culture, and the intensity of the reaction was read macroscopically and microscopically and scored as strong, moderate, weak, or negative by the method of Arden and Barksdale (4).

(v) Production of hydrogen sulfide. Many corynebacteria require an organic source of sulfur. Cystine is commonly provided to meet that need. On Tinsdale medium, those bacteria which produce a cystinase show a brown halo of telluride around their colonies (resulting from the reaction of liberated $\mathrm{H}_{2} \mathrm{~S}$ with tellurium).

Tubes of a soft-agar medium modified from that of Pisu $(53,59)$ were also used for detecting $\mathrm{H}_{2} \mathrm{~S}$ production as lead sulfide. This medium contained $80 \mathrm{ml}$ of molten $0.5 \%$ neopeptone infusion agar, $1 \mathrm{ml}$ of $10 \%$ (wt/vol) sterile aqueous lead acetate, $6 \mathrm{ml}$ of cystine solution, and $20 \mathrm{ml}$ of horse serum and was dispensed in $2-\mathrm{ml}$ amounts in test tubes (12 by $125 \mathrm{~mm}$ ). The cystine solution was prepared by dissolving first $1 \mathrm{~g}$ of $\mathrm{Na}_{2} \mathrm{CO}_{3}$ and then $1 \mathrm{~g}$ of cystine in $10 \mathrm{ml}$ of boiling distilled water, adding $90 \mathrm{ml}$ of distilled water, and autoclaving at $105^{\circ} \mathrm{C}$ for $20 \mathrm{~min}$. Butts of agar which received a heavy inoculum of bacteria from a capillary pipette were incubated at $30^{\circ} \mathrm{C}$ for 3 days and were then examined for the development of a black color.

(vi) Deamidation of pyrazinamide. It has been found by Sulea and Barksdale (manuscript in preparation) that the capacity to produce pyrazine carboxylamidase is lacking in those corynebacteria which were early associated with human and animal infections but that it is present in almost all other corynebacteria and in several species of Nocardia. The medium, modified from Wayne (71), contains the following ingredients per liter of distilled water: Dubos broth base (Difco), $6.5 \mathrm{~g}$; pyrazinamide, $0.1 \mathrm{~g}$; pyruvic acid, sodium salt, $2.0 \mathrm{~g}$; and agar, $15.0 \mathrm{~g}$. The molten agar mixture was dispensed in 5-ml amounts in screwcapped tubes ( 16 by $125 \mathrm{~mm}$ ) and autoclaved at $15 \mathrm{lb} /$ in $^{2}$ for $15 \mathrm{~min}$. The tubes were allowed to cool in an upright position and thus yielded a column of agar. Tubes were inoculated with $0.5 \mathrm{ml}$ of a dense suspension of bacteria and were incubated overnight at $30^{\circ} \mathrm{C}$. The presence or absence of pyrazinoic acid was determined by adding $1 \mathrm{ml}$ of freshly prepared $1 \%$ (wt/vol), aqueous solution ferrous ammonium sulfate to each tube and refrigerating the tubes for $4 \mathrm{~h}$ before reading. The development of a pink band in the tube as a result of the formation of a ferrous complex with pyrazinoic acid indicated pyrazinamidase activity in the culture.

(vii) Fermentation of carbohydrates. Differentiation disks (Difco) were aseptically added to $5 \mathrm{ml}$ of sterile phenol red broth (Difco) in screw-capped tubes (16 by $125 \mathrm{~mm}$ ). In the case of glycerol, dextrin, and starch (laundry), disks were not available, so, for testing, these agents were combined with phenol red broth (Difco) in 1,1 , and $0.4 \%$ (wt/vol) amounts, respectively. Bacteria to be tested were added as single-drop suspensions from a washed and resuspended 18-h-old culture. Incubation was at $30^{\circ} \mathrm{C}$. Because of the rapid alkaline reversal which sometimes occurs with corynebacteria, tubes were inspected at the end of day 1 , at $24 \mathrm{~h}$, and daily for 2 to 3 weeks. Only those tubes showing a definite acid reaction (lemon yellow) were recorded as positive.

(viii) Hydrolysis of polyoxyethylene sorbitan conjugates. Polyoxyethylene sorbitan monooleate (Tween 80 ) was added to $0.067 \mathrm{M}$ phosphate buffer ( $\mathrm{pH} 7.0$ ) in a final concentration of $0.5 \%$ ( $\mathrm{vol} / \mathrm{vol}$ ) along with $0.002 \%$ (wt/vol) neutral red (adjusted for dye content). Other types of Tween, monostearate (Tween 60), monopalmitate (Tween 40), and monolaurate (Tween 20), were used in similar concentrations. Medium was dispensed in 2-ml amounts in screw-capped tubes ( 16 by $125 \mathrm{~mm}$ ) and was sterilized at $121^{\circ} \mathrm{C}$ for $10 \mathrm{~min}$. Inoculated tubes were incubated for 5 days. A change of color from straw to pink or red indicated the liberation of fatty acid from the Tween, i.e, a positive reaction. For further details, see reference 72 .

(ix) Hydrolysis of sodium hippurate. Tubes of BHI broth containing $1 \%$ (wt/vol) sodium hippurate were inoculated and incubated for 5 days. A sample from each tube was clarified by centrifugation. To 0.8 
$\mathrm{ml}$ of clear supernatant was added $0.2 \mathrm{ml}$ of acid ferric chloride (49); the contents were then thoroughly mixed. A positive reaction was indicated by the presence of an insoluble brownish precipitate; unless a persistent precipitate was formed, the reaction was recorded as negative.

(x) Decarboxylation of ornithine and lysine. LLysine or L-ornithine $(1 \%$, wt/vol) was added to a broth medium (yeast extract, $3 \mathrm{~g}$ /liter; peptone, $5 \mathrm{~g} /$ liter; glucose, $1 \mathrm{~g} /$ liter) at $\mathrm{pH} 6.7$ to 6.8 to which $0.025 \%$ (wt/vol) bromocresol purple had been added before sterilization. Readjustment of the $\mathrm{pH}$ was required after the addition of ornithine. Inoculated tubes were examined daily for 5 days. A shift in the indicator from yellow to violet to reddish violet indicated a positive reaction (26).

(xi) Final hydrogen ion concentration in buffered peptone glucose broth. Buffered peptone glucose broth was inoculated and incubated for 5 days. Methyl red $(0.02 \%)$ was then layered onto the surface of the broth. A red color was interpreted as a positive reaction, and an orange-red color was interpreted as a weakly positive reaction. $E$. coli strain W was used as a positive control (26).

(xii) Production of acetoin. After inoculated tubes of glucose broth were incubated for 5 days, an alcoholic solution of $\alpha$-naphthol, followed by $\mathrm{KOH}$, was added to the cultures by the method of Edwards and Ewing (26). The development within $30 \mathrm{~min}$ of a red band starting at the surface of the medium indicated a positive reaction.

(xiii) Gelatinase. Gelatin, prepared by the procedure of Frazier (27) as adapted by Barer (9), was dispensed in $60-\mathrm{mm}$ diameter plastic petri dishes, singly inoculated, incubated at $30^{\circ} \mathrm{C}$ for 3 days, and then flooded with acid mercuric chloride $\left(\mathrm{HgCl}_{2}, 15 \mathrm{~g}\right.$; concentrated $\mathrm{HCl}, 20 \mathrm{ml}$; distilled water, $100 \mathrm{ml}$ ). A clear area surrounding the bacterial growth indicated that gelatin had been hydrolyzed, e.g., as with $C$. pyogenes strain $637 \mathrm{~S}$.

(xiv) Nitrate reductase. The method described by Arden and Barksdale for determining nitrate reduction (5) was followed. Broth cultures were incubated at $30^{\circ} \mathrm{C}$ both aerobically and anaerobically $(10 \%$ $\mathrm{CO}_{2}-\mathrm{N}_{2}, 3 \mathrm{lb} / \mathrm{in}^{2}$ ) and were qualitatively tested at 3,7 , 14 , and 21 days for the reduction of nitrate to nitrite. Results were read by the method of Arden and Barksdale (5) and were recorded in the following way: strong, dark reddish-brown; moderate, red; weak, pink; or negative, no color change. A negative result was further confirmed by the development of a red color upon addition of zinc dust (70).

(xv) Test for the hydrolysis of urea. Urea broth base (Difco; no added agar; containing phenol red) was combined with 9 parts of sterile distilled water and aseptically dispensed into screw-capped tubes to yield a column of medium $25 \mathrm{~mm}$ high. Medium was inoculated with 1 drop of a heavy suspension of actively growing culture (71). Those cultures which produced a change in the indicator resulting in a pink to red color were further checked for the presence of ammonia by mixing them with Nessler reagent. The development of a characteristic orange to brickish color was accepted as proof of the presence of ammonia. (xvi) Proteolytic action on milk. Milk agar (1.5\% PGT agar supplemented with $2 \%$ maltose, $0.25 \%$ yeast extract, and $10 \%$ skim milk) was inoculated with drops from overnight broth cultures and incubated at $30^{\circ} \mathrm{C}$ for 3 days. For detecting clearing in the milk, plates were flooded with $1 \%$ (vol/vol) aqueous $\mathrm{HCl}$.

(xvii) Growth in the presence of "nonphysiological" concentrations of sodium chloride. OrlaJensen stressed the capacity of $M$. flavum to grow at high concentrations of sodium chloride. $\mathrm{NaCl}$ was added to BHI medium (1.5\% agar) to yield one of the following concentrations (wt/vol); $0.5,2.5,5.0,7.5$, or $10.0 \%$. Batches of each concentration were poured into petri dishes. From actively growing cultures, approximately $10^{5}$ colony-forming units was spread over the plates, which were then incubated for 10 days, after which the plates were inspected for inhibition of growth.

(xviii) Detection of alkaline phosphatase. A 20$\mathrm{ml}$ amount of $0.5 \%$ (wt/vol) phenolphthalein diphosphate (sodium salt solution) in water, sterilized through a 0.45- $\mu \mathrm{m}$ membrane filter (Millipore Corp.), was added to 1 liter of sterile molten nutrient agar (Difco). Exposure of bacteria grown on this medium to vapors of concentrated ammonium hydroxide yielded a bright pink to red color in cultures of those strains which hydrolyzed phenolphthalein diphosphate (50).

(xix) Assessment of nutritional requirements of M. flavum. As a starting medium, the modification of Mueller-Miller medium called PGT by Barksdale and Pappenheimer $(14,56)$ was employed. This medium contains $30 \mathrm{~g}$ of an acid hydrolysate of casein (Casamino Acids; Difco) per liter, $2 \mathrm{ml}$ of an accessories and minerals solution $\left(\mathrm{MgSO}_{4} \cdot 7 \mathrm{H}_{2} \mathrm{O}, 22.5 \mathrm{~g}\right.$ $\mathrm{CuSO}_{4} \cdot 5 \mathrm{H}_{2} \mathrm{O}, 1 \%$ solution, $5.0 \mathrm{ml} ; \mathrm{ZnSO}_{4} \cdot 5 \mathrm{H}_{2} \mathrm{O}, 1 \%$ solution, $4.0 \mathrm{ml} ; \mathrm{MnCl}_{2} \cdot 4 \mathrm{H}_{2} \mathrm{O}, 1 \%$ solution, $1.5 \mathrm{ml}$; beta-alanine, $0.115 \mathrm{~g}$; nicotinic acid, $0.115 \mathrm{~g}$; pimelic acid, $0.0075 \mathrm{~g}$; and water to make $100 \mathrm{ml}), 2.5 \mathrm{ml}$ of a source of ferrous iron $\left(\mathrm{FeSO}_{4} \cdot 7 \mathrm{H}_{2} \mathrm{O}, 1.0 \mathrm{~g}\right.$; concentrated $\mathrm{HCl}, 1.0 \mathrm{ml}$; and distilled water to make 100.0 $\mathrm{ml}), 1 \mathrm{ml}$ of a cystine solution as an organic source of sulfur (cystine, $20 \mathrm{~g}$; concentrated $\mathrm{HCl}, 20 \mathrm{ml}$; and water to make $100 \mathrm{ml}$ ), and $100 \mathrm{ml}$ of an energy source combined with calcium ions (maltose, $20 \mathrm{~g} ; \mathrm{CaCl}_{2}$. $2 \mathrm{H}_{2} \mathrm{O}, 0.3 \mathrm{~g}$; and water to make $100 \mathrm{ml}$ ). To 1 liter of the completed medium were added $1.1 \mathrm{mg}$ of calcium pantothenate, $0.5 \mathrm{mg}$ of glutamic acid, and $0.1 \mathrm{mg}$ of tryptophane. The medium minus the maltose-calcium chloride solution and the maltose-calcium chloride solution were autoclaved separately. The medium was completed by the addition of the maltose-calcium chloride solution and was incubated for sterility. By omission of various components of this medium, it was found that $M$. flavum strain 8 of Orla-Jensen did not require an organic sulfur source (i.e., cystine) and did not need nicotinic acid, $\beta$-alanine, and pimelic acid. Furthermore, the additional glutamic acid in the PGT medium inhibited the growth of $M$. flavum.

Next, the completely defined medium of Drew and Mueller (25) was employed in an effort to ascertain the minimal nutritional needs of $M$. flavum strain 8 for growth. The trace metals (minerals) were the same as those used in Mueller-Miller medium. In their original formula, Drew and Mueller failed to include phos- 
phate. In the present use of their formula, we added 1 $\mathrm{g}$ of $\mathrm{KH}_{2} \mathrm{PO}_{4}$ per liter, $1.2 \mathrm{~g}$ of $\mathrm{Na}_{2} \mathrm{HPO}_{4}$ per liter, and $25 \mathrm{mg}$ of ferrous iron per liter. The other accessories and sources of carbon required for optimal growth (optical density $16 \approx 0.896 \mathrm{~g}$ of bacterial $\mathrm{N}$ per liter) are shown in Table 1.

(xx) Phage susceptibility. Stocks of phage were prepared by methods previously described $(36,44)$. Test dilution drops which gave complete lysis, confluent lysis, or individual plaques on the indicator strains employed for the production of the phage stock were placed on lawns (prepared from actively growing cells) of the organism to be tested. Susceptibility to a given phage was recorded only when individual plaques of that phage developed on the bacterial strain being tested.

Analysis of lipids. (i) Extraction of free lipids. Cells were suspended in chloroform-methanol (2:1) and stirred overnight at room temperature. Combined extracts were evaporated and stored at $-20^{\circ} \mathrm{C}$.

(ii) Fractionation of polar lipids. Lipid extracts were chromatographed on diethylaminoethyl-cellu- lose (acetate form) by the method of Rouser et al. (64). Fractions were first characterized by thin-layer chromatography, using the following solvent systems: chloroform-methanol-water (65:25:4); chloroformmethanol-7 $\mathrm{N} \mathrm{NH}_{4} \mathrm{OH}$ (60:35:4); and chloroform-acetone-methanol-water-acetic acid (5:2:1:0.5:1). The following were used as specific spray reagents: anthrone reagent for sugars; ninhydrin reagent for free amino groups; and Dittmer-Lester (24) spray for phospholipids. All lipids were visualized with $20 \% \mathrm{H}_{2} \mathrm{SO}_{4}$ followed by charring. Purification of lipids was carried out on a Mallinckrodt CC 7 silicic acid column, using mixtures of chloroform and methanol as eluents. Purity of the polar lipids was checked by two-dimensional thinlayer chromatography.

(iii) Identification of polar lipids. (a) Hydrolyses. Acidic hydrolysis was performed in sealed tubes at $110^{\circ} \mathrm{C}$ overnight by using $1 \mathrm{~N} \mathrm{HCl}$ for sugars and 6 $\mathrm{N} \mathrm{HCl}$ for amino acids. Alkaline hydrolysis was carried out with $5 \% \mathrm{KOH}$ in benzene-methanol $(2: 8)$ at $70^{\circ} \mathrm{C}$ overnight. After acidification, lipids were extracted with ether, and the hydrosoluble phase was examined

TABLE 1. Nutritional requirements of various corynebacteria grown in the presence of trace metals and sugars

\begin{tabular}{|c|c|c|c|c|c|}
\hline \multirow[b]{2}{*}{ Accessory growth factors } & \multicolumn{5}{|c|}{ Growth of: ${ }^{\alpha}$} \\
\hline & $\begin{array}{c}\text { Microbacterium } \\
\text { flavum }^{b}\end{array}$ & $\begin{array}{c}\text { Coryne- } \\
\text { bacterium } \\
\text { diphtheriae } \\
\text { PW8 }^{\text {b. }}\end{array}$ & C. renale ${ }^{d_{i}}$ & C. pilosum e.f & C. cystitidis $e^{e^{\prime}}$ \\
\hline $\bar{\beta}$-Alanine & - & $+(2.3 \mathrm{mg})^{g}$ & $-{ }^{h}$ & - & - \\
\hline L-Cystine & - & $+(0.2 \mathrm{~g})$ & - & - & $+(50 \mathrm{mg})$ \\
\hline L-Glutamic acid $\mathrm{HCl}$ & $+(7.4 \mathrm{~g})^{i}$ & $+(8.0 \mathrm{~g})$ & $+(10 \mathrm{~g})$ & $+(10 g)$ & $+(10 \mathrm{~g})$ \\
\hline Glycine & e $(0.24 \mathrm{~g})$ & $\mathrm{e}(0.24 \mathrm{~g})$ & - & - & - \\
\hline L-Isoleucine & $+(0.5 \mathrm{~g})$ & - & - & - & $+(0.5 \mathrm{~g})$ \\
\hline DL-Leucine & e $(0.8 \mathrm{~g})$ & $\mathrm{e}(0.8 \mathrm{~g})$ & - & - & - \\
\hline DL-Methionine & $+(0.27 \mathrm{~g})$ & $\mathrm{e}(0.27 \mathrm{~g})$ & - & - & $+(0.3 \mathrm{~g})^{j}$ \\
\hline L-Proline & $+(0.16 \mathrm{~g})$ & e $(0.16 \mathrm{~g})$ & - & - & - \\
\hline DL-Tryptophane & - & $\mathrm{e}(0.12 \mathrm{~g})$ & - & - & - \\
\hline DL-Valine & $\mathrm{e}(1.2 \mathrm{~g})^{j}$ & $\mathrm{e}(1.2 \mathrm{~g})$ & $+(1.2 \mathrm{~g})^{j}$ & - & $+(1.2 \mathrm{~g})^{j}$ \\
\hline p-Aminobenzoic acid & $+(1.0 \mathrm{mg})$ & - & - & $+(10 \mathrm{mg})$ & - \\
\hline Biotin & $+(2.0 \mathrm{mg})$ & - & $+(0.5 \mathrm{mg})$ & $+(0.5 \mathrm{mg})$ & $+(0.5 \mathrm{mg})$ \\
\hline Nicotinic acid & $+(2.3 \mathrm{mg})$ & $+(2.3 \mathrm{mg})$ & - & $+(10 \mathrm{mg})$ & $+(10 \mathrm{mg})$ \\
\hline Pantothenate, calcium & $+(1.0 \mathrm{mg})$ & - & $+(10 \mathrm{mg})$ & - & - \\
\hline Pimelic acid & - & $+(0.15 \mathrm{mg})$ & $-k$ & $-{ }^{*}$ & $-^{*}$ \\
\hline Pyridoxine $\mathrm{HCl}$ & - & - & - & - & $+(10 \mathrm{mg})$ \\
\hline Thiamine $\mathrm{HCl}$ & $+(1.0 \mathrm{mg})$ & $+(0.24 \mathrm{mg})$ & $+(10 \mathrm{mg})$ & - & $+(10 \mathrm{mg})$ \\
\hline Glucosamine & - & NT & - & - & $+(0.5 \mathrm{~g})$ \\
\hline Inositol & - & $\mathbf{N T}$ & $+(0.5 \mathrm{~g})$ & - & - \\
\hline Carbon source & Galactose $(20 \mathrm{~g})$ & Maltose (14 g) & Glucose $(10 \mathrm{~g})$ & Glucose $(10 \mathrm{~g})$ & Glucose $(10 \mathrm{~g})$ \\
\hline
\end{tabular}

a Symbols: +, Required for growth; - not required for growth; e, enhances growth from minute inocula; NT, requirement not reported as having been tested. Ammonium ion, provided as $\left(\mathrm{NH}_{4}\right)_{2} \mathrm{SO}_{4}$, at approximately $2.4 \mathrm{~g} / \mathrm{liter}$, was found necessary for maximal growth of $C$. diphtheriae, $C$. renale, $C$. cystitidis, and $C$. pilosum.

${ }^{6}$ Growth of these strains was markedly stimulated by sodium pyruvate, e.g., $0.7 \mathrm{~g} /$ liter for $M$. flavum strain 8 and $3.6 \mathrm{~g} /$ liter for $C$. diphtheriae PW8. Although these findings agree in some respects with those of Skerman and Jayne-Williams (67), it is difficult to compare nutritional studies carried out under semidefined conditions with those in which completely defined media were employed.

From reference 25 .

¿ From reference 33 .

- Nutritional requirements reported in reference 33 were modified somewhat from those reported in reference 34.

$f$ From references 33 and 76.

- Values in parentheses are the amounts (per liter) which were added to get the indicated responses.

$h$ There is no evidence that $\beta$-alanine could replace pantothenic acid in this case.

'Provided as sodium glutamate.

i Provided as the $\mathrm{L}$ isomer.

${ }^{k}$ It is not known whether pimelic acid could replace the biotin requirement. 
by paper chromatography. Hydrosoluble phases were analyzed on Whatman no. 1 paper, and the chromatograms were developed with butanol-pyridine-water (6:4:3) and butanol-acetic acid-water (4:1:1) solvent systems.

Chromatograms were revealed with $p$-anisidine $\mathrm{HCl}$ and $\mathrm{AgNO}_{3}-\mathrm{NaOH}$ for sugars and polyols. Ninhydrin reagent was also employed for amino acids.

(b) Fatty acid analyses. Fatty acids derived from the polar lipids were methylated with diazomethane and separated on Kieselgel $G$ thin-layer plates developed with petroleum ether-ether (8:2). The hydroxy fatty esters were then analyzed on silver nitrate-impregnated Kieselgel chromatograms, which were developed with benzene-ether (8:2); the fractions were visualized with dichlorofluorescein. Saturated and mono- and diunsaturated hydroxy esters were scraped off the plates and eluted with ether.

(c) Gas-liquid chromatography. Gas-liquid chromatography was performed with a Varian Aerograph 1400 apparatus. Mycolic esters were pyrolyzed on two kinds of stainless steel columns (length, $2.5 \mathrm{~m}$ ), one containing $10 \% \mathrm{SE} 30$ on chromosorb $\mathrm{W}$ and the other containing $20 \%$ diethylene glycol succinate on chromosorb W.

For pyrolysis, the injection temperature was $295^{\circ} \mathrm{C}$. Mycolic esters were also chromatographed as trimethylsilyl ethers on stainless steel columns (length, $1 \mathrm{~m}$ ) containing $10 \%$ SE 30 on chromosorb W. Sugars were also characterized as trimethylsilyl derivatives on an SE 52 chromosorb W column (68). Fatty esters were analyzed on polar and nonpolar columns. All peaks were identified by injection with authentic standards.

G $+C$ content of DNA and DNA homology. (i) DNA isolation and purification. Bacterial DNA was isolated by using a modification of the procedure of Mizuguchi and Tokunaga (54). Glycine-treated cells were suspended at a concentration of about $5 \times 19^{9}$ colony-forming units per $\mathrm{ml}$ in TES buffer [0.03 M tris(hydroxymethyl)aminomethane, $0.006 \mathrm{M}$ disodium ethylenediaminetetraacetate, $0.05 \mathrm{M} \mathrm{NaCl}, \mathrm{pH} 8.0$ ]. Lysozyme (catalog no. L-6876; Sigma; $2 \mathrm{mg} / \mathrm{ml}$ in TES) and heat-treated $\left(100^{\circ} \mathrm{C}, 10 \mathrm{~min}\right)$ ribonuclease (catalog no. R-4875; Sigma; $2 \mathrm{mg} / \mathrm{ml}$ in TES) were added to final concentrations of $0.2 \mathrm{mg} / \mathrm{ml}$, and the suspension was incubated at $50^{\circ} \mathrm{C}$ for $30 \mathrm{~min}$. If no significant lysis occurred, as indicated by a decrease in the turbidity and an increase in the viscosity of the suspension, lytic enzyme 2 (Kyowa Hakko U.S.A. Inc., New York, N.Y; $1 \mathrm{mg} / \mathrm{ml}$ in TES) was added to a final concentration of $0.1 \mathrm{mg} / \mathrm{ml}$, and the suspension was further incubated at $50^{\circ} \mathrm{C}$ for $30 \mathrm{~min}$. Cell lysis was then completed by adding sodium dodecyl sulfate (Fisher Scientific Co.) to a concentration of $1 \%$ (wt/ vol). After the lysate was chilled in an ice bath, an equal volume of chloroform (Fisher)-isoamyl alcohol (Baker Chemical Co.) (24:1, vol/vol) (52) was added to it, and the mixture was gently shaken by hand for $20 \mathrm{~min}$. The mixture was then centrifuged at $4^{\circ} \mathrm{C}$ for $10 \mathrm{~min}$ at $4,080 \times g$, and the top, aqueous layer was decanted into a graduated cylinder. The DNA solution was brought to $0.15 \mathrm{M}$ with respect to $\mathrm{NaCl}$ and overlaid with 2 volumes of cold $95 \%$ ethyl alcohol. DNA was collected at the interface, washed in $95 \%$ ethyl alcohol, and air dried.
Crude DNA was further purified with cetyltrimethylammonium bromide by the method of Baess (8), dissolved in sterile $0.1 \times$ SSC buffer $(1 \times \mathrm{SSC}=0.15 \mathrm{M}$ $\mathrm{NaCl}$ plus $0.015 \mathrm{M}$ sodium citrate, $\mathrm{pH} 7.0$ ), and stored at $-15^{\circ} \mathrm{C}$. The concentrations of DNA in stock solutions were determined by measuring the optical density at $260 \mathrm{~nm}$. The presence of double-stranded DNA in a preparation was confirmed by a hyperchromic shift at $260 \mathrm{~nm}$ after alkaline denaturation.

(ii) $\mathrm{G}+\mathrm{C}$ content of DNA. The G+C content (in moles percent) of bacterial DNA was determined by thermal denaturation. DNA stock solutions were diluted to about $50 \mu \mathrm{g} / \mathrm{ml}$ in $0.1 \times$ SSC buffer. Thermal denaturation was carried out at a heat rate of $1^{\circ} \mathrm{C} /$ min while hyperchromicity at $260 \mathrm{~nm}$ was monitored with a Gilford model 2527 thermal cuvette system. A melting temperature $\left(T_{m}\right)$ was graphically determined for each DNA sample, and respective $\mathrm{G}+\mathrm{C}$ contents were calculated by using the formula: $\mathrm{mol} \% \mathrm{G}+\mathrm{C}=$ $100 \times\left[\left(T_{m} / 50.2\right)-0.990\right]$ (51). DNA from $E$. coli $\mathrm{K}$ 12 ATCC 23724 was used as a control reference standard.

(iii) DNA-DNA hybridization. Free-solution DNA-DNA hybridization was performed as described by DeLey et al. (23) and as modified by Bradley and Mordarski (16) and by W. Trejo, Squibb Institute for Medical Research, Princeton, N.J. (personal communication). Two different DNA stock solutions were diluted in $0.1 \times \mathrm{SSC}$ to about $150 \mu \mathrm{g} / \mathrm{ml}$ and sheared by passing 10 times through a 26-gauge needle attached to a 5-ml syringe. An equal volume of $50 \%$ (vol/ vol) formamide (catalog no. F-95; Fisher) in 12× SSC buffer was added to each sample. The contents of four Gilford model 2527 thermal cuvettes were heat-denatured at $95^{\circ} \mathrm{C}$ for $1 \mathrm{~min}$; one of these cuvettes contained $25 \%$ (vol/vol) formamide in $6.05 \times \mathrm{SSC}$ buffer (blank); the second contained DNA sample 1, the third contained DNA sample 2, and the fourth contained a mixture of equal volumes of samples 1 and 2 . The samples were then rapidly cooled with circulating cold water and a Gilford 2527 thermoprogrammer set for $70^{\circ} \mathrm{C}$. The hybridization process at $70^{\circ} \mathrm{C}$ was recorded as a decrease in adsorbance at $270 \mathrm{~nm}$ and was monitored in a Gilford 250 spectrophotometer equipped with a reference compensator, a 6046 analog multiplexer, and a 6050 recorder. A rate $(V)$ was established for each reaction by observing the degree of hypochromicity relative to time. Homologies were calculated from the equation proposed by DeLey and co-workers (23): \% homology $=100 \times\left\{\left[4 V_{\text {mix }}-\left(V_{1}+\right.\right.\right.$ $\left.\left.\left.V_{2}\right)\right] / 2 \sqrt{V_{1} V_{2}}\right\}$, where $V_{1}$ is the rate determined for DNA sample $1, V_{2}$ is the rate determined for DNA sample 2, and $V_{\text {mix }}$ is the rate determined for the mixture of DNA samples 1 and 2.

\section{RESULTS}

Microbacterium flavum strain 8 grew as raised, smooth, butyrous, cream to faintly yellow colonies on nutrient or BHI agar and formed (by 2 days) dome-shaped, black colonies with grayblack perimeters on chocolate tellurite agar. Well-isolated, 10-day-old colonies exhibited grayish-black margins and a raised, leached 
grayish-white central umbo. In a defined medium, the mean generation time of strain 8 was $160 \mathrm{~min}$ and in $\mathrm{BHI}$ medium it was $87 \mathrm{~min}$. On Loefflers medium slants, yellow pigmentation was evident. The cells of this pleomorphic, rodshaped bacterium were nonmotile, nonsporeforming, gram positive to gram variable, and non-acid (acidic ethanol)-fast and exhibited moderate tapering at their ends; when grown on a phosphate-rich medium, the cells contained numerous metachromatic granules. Strain 8 produced barely detectable amounts of intracellular starch from glucose 1-phosphate. It failed to deaminate pyrazinamide and to reduce nitrate to nitrite. It was urease and alkaline phosphatase negative. It failed to produce $\mathrm{H}_{2} \mathrm{~S}$ in the presence of either an organic or an inorganic source of sulfur. It failed to ferment lactose or xylose (as well as arabinose, adonitol, dulcitol, dextrin, glycerin, inositol, inulin, maltose, melibiose, raffinose, rhamnose, salicin, sorbitol, starch, sucrose, or trehalose) but fermented glucose, fructose, galactose, mannose, and mannitol. In addition to trace metals and a carbon source, it required the following for luxuriant yields of growth (ca. $1 \mathrm{~g}$ of bacterial $\mathrm{N}$ per liter): glutamic acid, isoleucine, methionine, proline, $p$-aminobenzoic acid, biotin, nicotinic acid, pantothenic acid, and thiamine (Table 1). It was methyl red positive and gave a positive Voges-Proskauer reaction. It did not hydrolyze sodium hippurate, did not show proteolytic action on gelatin or on milk agar, and did not produce an ornithine or a lysine decarboxylase. It failed to hydrolyze sorbitan oleate, but it did hydrolyze sorbitan laurate, sorbitan palmitate, and sorbitan stearate. Certain of its reactions differed from those of $C$. diphtheriae, C. renale, C. pseudodiphtheriticum, and C. xerosis (Table 2).

$M$. flavum strain 8 was seeded onto a series of BHI agar plates containing $0.5,2.5,5.0,7.5$, and $10 \%$ sodium chloride. On similar plates were seeded $C$. diphtheriae strains C7, HF, and PW8. Both $\mathrm{C} 7$ and strain 8 grew as very tiny colonies in the presence of $10 \%$ salt. Growth was rather normal on plates containing $7.5 \%$ salt. The growth of strain HF was completely inhibited in the presence of $10 \%$ salt, as was that of strain PW8. Furthermore, there was much growth inhibition of PW8 on plates containing $7.5 \%$ salt but normal growth in the presence of $5 \%$ salt. HF grew well at a salt concentration of $7.5 \%$.

Corynebacteriophages active on some strains of C. diphtheriae (gravis), C. diphtheriae (mitis), C. ulcerans, C. renale, and Nocardia aster. oides failed to form plaques on lawns of $M$. flavum strain 8. Supernatant fluids obtained from overnight cultures of $M$. flavum strain 8 showed no plaque-forming ability on either the

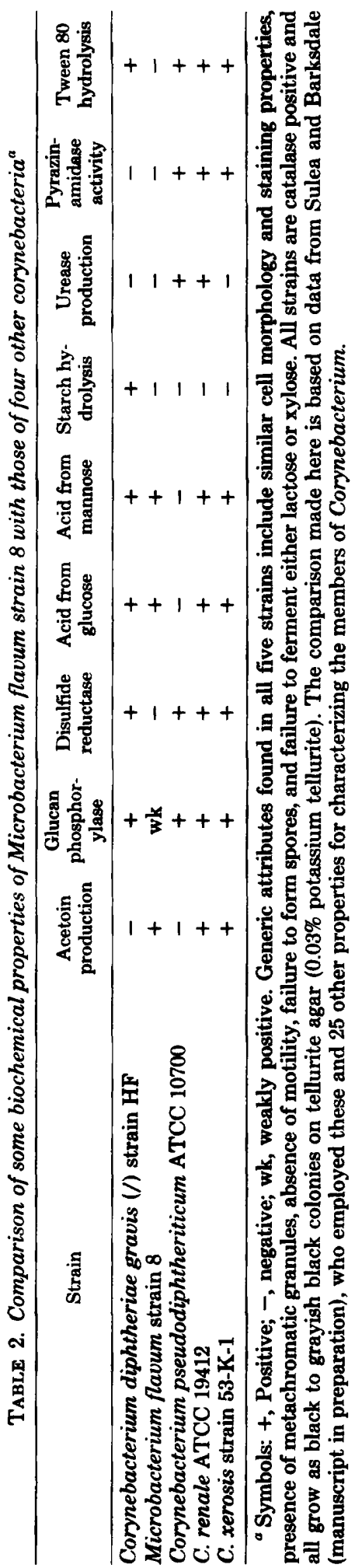


above-mentioned bacteria or on selected strains of C. minutissimum, C. cystitidis, C. pseudotuberculosis, C. genitalium, Brevibacterium vitarumen, Brevibacterium liquefaciens, and Bacterionema matruchotii and on Corynebacterium sp. strain 43 (see above). Supernatants of these strains failed to form plaques on lawns of $M$. flavum strain 8 .

It has been shown repeatedly that $M$. flavum strain 8 has a cell wall peptidoglycan of the basic structure found in the Corynebacterium-Mycobacterium-Nocardia group $(22,41,63,65,74)$, i.e., direct cross-linkage in which the amino group of the D-asymmetric carbon of meso-diaminopimelic acid forms a peptide bond with the carboxyl group of $D$-alanine from a neighboring peptide subunit. This, in conjunction with an arabinogalactan and arabinomannan polymer linked to mycolic acids, distinguishes the walls of the Corynebacterium-Mycobacterium-Nocardia group $(7,11,21,39,42,60,61)$. Previous screening of $M$. flavum strain 8 for lipids has indicated the presence of mycolic acids (30).

One aim of this study was to characterize further the lipids of $M$. flavum strain 8 in an effort to assess them in terms of lipid patterns already established for the CorynebacteriumMycobacterium-Nocardia group (6, 17, 47). Analyses of the fatty esters of the free lipids from strain 8 revealed a mixture of straightchain, saturated and unsaturated acids having an even number of carbon atoms (Table 3). Two branched fatty acids were also present, the chromatographic behaviors of which were in agreement with an iso-anteiso structure. On the basis of thin-layer chromatographic analysis of $M$. flavum strain 8 , it had already been suggested that that organism produced esters of corynomycolic acid $(30,40)$. From the corynomycolic acid fraction isolated by us, a mixture of saturated, monounsaturated, and diunsaturated hydroxy esters was separated on silver nitrate-impregnated thin-layer chromatography plates. This method served to separate the unsaturated esters into five groups: those with a single double bond located in the side chain (Fig. 1, group $\mathrm{II}_{\mathrm{a}}$ ), those having a single double bond in the main chain (group $\mathrm{II}_{b}$ ), and diunsaturated esters having a double bond in each chain (group IV)(Fig. 1). Although the partitioning of the two other groups of unsaturated esters (groups III $_{a}$ and $\mathrm{III}_{\mathrm{b}}$ ) remains to be explained, perhaps there are two double bonds located in the same chain, as postulated for $C$. xerosis (2). Nevertheless, the presence of $\mathrm{C}_{32}, \mathrm{C}_{34}$, and $\mathrm{C}_{36}$ corynomycolic acids from the cells of $M$. flavum strain 8 further strengthens the argument for the essentially corynebacterial nature of this microbe.

We found that the polar lipids from $M$. flavum
TABLE 3. Composition of fatty esters from free lipids of Microbacterium flavum strain 8

\begin{tabular}{cc}
\hline Chain length of fatty ester & $\begin{array}{c}\text { \% of fatty ester relative } \\
\text { to total acids }\end{array}$ \\
\hline $14: 0^{a}$ & 2 \\
15 branched & 22.2 \\
$16: 1$ & 2 \\
$16: 0$ & 31.6 \\
17 branched & 4.6 \\
$18: 1$ & 33.3 \\
$18: 0$ & 4.4 \\
\hline
\end{tabular}

a The first number refers to the number of carbon atoms, and the second number refers to the number of double bonds.

strain 8 consist of phospholipids and a main glycolipid. The phospholipids proved to be diphosphatidyl glycerol (cardiolipin), phosphatidyl glycerol, phosphatidyl inositol, and phosphatidylinositol mannoside. Only traces of phosphatidyl ethanolamine were present (43). The main glycolipid fraction behaved differently from dimycolates of trehalose (cord factors). Yet trehalose was identified by paper and gas-liquid chromatography of the saponified glycolipid fraction. Furthermore, only glucose was detected after acid hydrolysis. Corynomycolic acid was present. In fact, the major components were corynomycolic acids and trehalose. Chromatographic migration of the major glycolipid component was similar to that of a monocorynomycolate of trehalose previously isolated from $B$. vitarumen (45) and quite different from that of dicorynomycolates of trehalose. It appears, then, that the cord factor of $M$. flavum strain 8 is a monocorynomycolate of trehalose.

The final preparation of nucleic acid from $M$. flavum strain 8 contained $215 \mu \mathrm{g}$ of DNA per $\mathrm{ml}$. In three thermal denaturation experiments, melting temperatures of $80.1,80.1$, and $80.2^{\circ} \mathrm{C}$ were obtained. Thus, the average $\mathrm{G}+\mathrm{C}$ content of the DNA of $M$. flavum strain 8 was $58.6 \mathrm{~mol} \%$. Standard DNA from Escherichia coli K-12 (used as a control in each experiment) yielded a melting temperature of $75.7^{\circ} \mathrm{C}(\mathrm{G}+\mathrm{C}$ content, $51.8 \mathrm{~mol} \%$ ), and DNA from C. diphtheriae PW8, used as a reference for homology studies, gave a melting temperature of $76.6^{\circ} \mathrm{C}(53.6 \mathrm{~mol} \% \mathrm{G}+\mathrm{C})$. The homology between the DNA of $M$. flavum strain 8 and that of $C$. diphtheriae PW8 was $64 \%$ under conditions where the homology between PW8 DNA and DNA from C. renale ATCC 19412 was only $34 \%$.

\section{DISCUSSION}

Orla-Jensen noted repeatedly in his treatise The Lactic Acid Bacteria (57) that Microbacterium flavum was different from most of the 

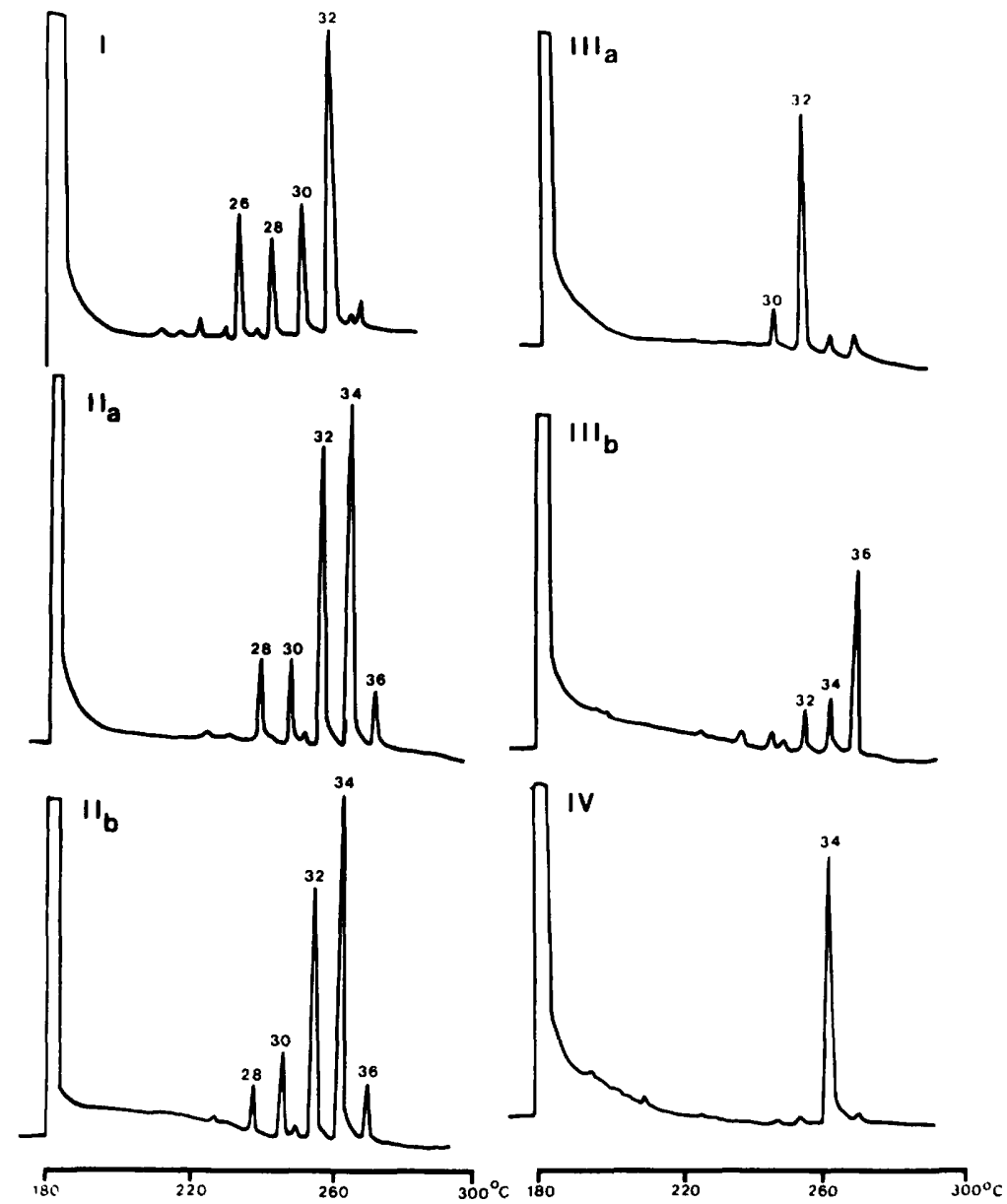

FIG. 1. Gas-liquid chromatography of the trimethylsilyl derivatives of the methyl esters of corynomycolic acids from Microbacterium flavum strain 8. The various fractions, numbered according to their decreasing mobilities $\left(I, I I_{a}, I I_{b}, I I I_{a}, I I I_{b}\right.$, and $\left.I V\right)$, were obtained by scraping off the bands from argentation (alkaline silver nitrate) thin-layer chromatography. Each fraction was submitted to pyrolytic gas chromatography and to gas-liquid chromatography (of the trimethylsilyl derivatives of the methyl corynomycolates). The figures above the peaks indicate the number of carbon atoms.

lactic acid bacteria discussed therein. Although it shared with them gram positivity, nonmotility, and inability to form spores and to ferment adonitol, it did not stain evenly with methylene blue, it produced catalase, it did not tolerate high concentrations of sugar (5 to $10 \%$ ), it did not have extremely exacting nutritional requirements (compared with lactobacilli), and it failed to hydrolyze either casein or gelatin. It grew well under aerobic conditions. Compared with most of Orla-Jensen's lactic acid bacteria, $\boldsymbol{M}$. flavum was relatively tolerant to salt: e.g., it grew well in $2.5 \%$, less well in $5.5 \%$, poorly in $10 \%$, and not at all in $15.5 \%$ sodium chloride contained in a casein peptone broth with $2 \%$ glucose. (Some of the cocci examined by him were able to grow in the presence of $15.5 \% \mathrm{NaCl}$.) Two strains of $M$. flavum, strains 8 and 9 , were employed for most studies, and strain 9 was more sensitive to salt than was strain 8 . We have reported here that strain 8 is only slightly more tolerant to salt than is $C$. diphtheriae. As pointed out above, only one of Orla-Jensen's original strains of $M$. flavum has survived to date, and attempts by bacteriologists (working with dairy materials and products) to isolate new strains have not been successful $(1,37)$. Jayne-Williams and Skerman (37) have discussed the scarcity of strains of $M$. flavum and the apparent difficulty of isolating such organisms from contemporary dairy products. Whether strain 8 found its way from the skin of a cow into the cheese from which it was 
recovered is not known. Wittern (73) reported that she had two isolates of $M$. flavum from milk, three from cheese, two from dung, and one from debris in a cow stall. However, the unavailability of these strains makes a present-day comparison of them with strain 8 impossible.

Orla-Jensen found that strain 8 ceased to grow well between 35.5 and $37.5^{\circ} \mathrm{C}$. In contrast, his Thermobacterium lactis (Lactobacillus lactis) grew at $50^{\circ} \mathrm{C}$. He reported that when cultures of $M$. flavum were subjected to $70^{\circ} \mathrm{C}$ for $15 \mathrm{~min}$, there was a decrease in viability from $1.6 \times 10^{6}$ to $1.7 \times 10^{4}$ colony-forming units per ml. Upon this experiment has rested the "heat resistance" of $M$. flavum, seriously used as a taxonomic property for many years $(1,18,73)$. Wittern (73), who worked with several strains of "M. flavum" in addition to Orla-Jensen's strain 8, found tolerance to $70^{\circ} \mathrm{C}$ limited to less than $5 \mathrm{~min}$. Robinson (62) found that $M$. flavum survived at $60^{\circ} \mathrm{C}$, but not at $65^{\circ} \mathrm{C}$, for $10 \mathrm{~min}$. He points out that his range of sensitivity to heat is comparable to that common to members of the genus Corynebacterium $(44,63)$. It is surprising that OrlaJensen did not, for comparative purposes, include in his studies known gram-positive pleomorphic organisms, such as C. xerosis, $C$. pseudodiphtheriticum, or even $C$. diphtheriae. Instead he used strains of $E$. coli, Klebsiella aerogenes, and Salmonella paratyphi.

Orla-Jensen had found $M$. flavum capable of reducing nitrates to nitrites. Wittern (73) had difficulty confirming this property, and we find strain 8 to be lacking an active nitratase. Robinson (62) found strain 8 and strain 19 to be nitratase negative.

In 1934, H. L. Jensen (38) published his studies on "saprophytic" mycobacteria and corynebacteria and proposed the transfer of Microbacterium flavum Orla-Jensen to Mycobacterium. Much of the support for his decision came from the acid fastness he ascribed to his organism: "this is the least acid-fast of all mycobacteria. In 2-3-days-old cultures some cells appear violet with red granules after staining with hot carbolfuchsin, differentiation with $5 \%$ sulfuric acid and counterstaining with aqueous methylene blue. In milk after 6-19 days many club-shaped cells appear deep violet, the rest as pure blue rods and cocci." This is an accurate description of the response of $C$. diphtheriae, $C$. xerosis, $C$. renale, etc. to such a staining procedure (31). Such fastness to decolorization with sulfuric acid is not equivalent to the acidic ethanol fastness, which characterizes many mycobacteria (12) and which can best be established by using the ZiehlNeelsen stain, a standard procedure in laboratories concerned principally with mycobacteria (70). Although Jensen chose Mycobacterium as the genus for Microbacterium flavum, he went to considerable lengths in pointing out the taxonomic closeness of Corynebacterium and $M y$. cobacterium, and he discussed the unreliability of morphology in establishing taxonomic relationships (38). In his comparative studies, however, he used no organisms designated as members of the genus Corynebacterium.

Keddie et al. (41) and Robinson (63), independently in 1966, found that cell wall hydrolysates of $M$. flavum strain 8 yield alanine, glutamic acid, and meso-diaminopimelic acid, as well as arabinose, galactose, and mannose. Robinson (63) found that strains 8 and 19 each produced a single catalase and a single esterase, and in both cases the enzymes with similar activities had similar electrophoretic mobilities. Schleifer (65) and others (74) reported that the murein of $M$. flavum strain 8 contains meso-diaminopimelic acid, glutamic acid and alanine at a molar ratio of $1: 1: 1.5$ to 1.7 and $1.8 \mathrm{~mol}$ of ammonia per mol of glutamic acid, suggesting that both mesodiaminopimelic acid and glutamic acid are present as amides. Yamada and Komagata (75) found the $\mathrm{G}+\mathrm{C}$ content of the DNA of $M$. flavum strain 8 to be $58.3 \mathrm{~mol} \%$; Collins-Thompson et al. (20) and Bousfield (15) reported values of 58.2 and $56 \mathrm{~mol} \%$, respectively, for this strain. These results agree with those reported herein (58.6 $\mathrm{mol} \%)$ for Orla-Jensen's strain 8 . We have reported here that the DNA of strain 8 exhibits a $64 \%$ homology with that of $C$. diphtheriae strain PW8.

As might be expected, the metabolic activities of $M$. flavum strain $8(20,62)$ are comparable to those which have been summarized for $C$. diphtheriae (11). Thus, $M$. flavum strain 8 possesses enzymes of the Embden-Meyerhof, hexose monophosphate, and tricarboxylic acid pathways, as indicated by the following demonstrated specific activities: hexokinase, 0.041; fructose diphosphate aldolase, 0.046 ; glucose-6phosphate dehydrogenase, $0.010 ; 6$-phosphogluconate dehydrogenase, 0.019 ; lactate dehydrogenase, 0.037 ; reduced nicotinamide adenine dinucleotide oxidase, 0.092 ; reduced nicotinamide adenine dinucleotide phosphate oxidase, 0.01 ; citrate synthetase, 0.054; aconitate hydratase, 0.109 ; isocitrate lyase, 0.320 ; succinate dehydrogenase, 0.050; fumarate hydratase, 0.075 ; and malate dehydrogenase, $0.478(20)$. Its division time is within the range already recorded for Corynebacterium, e.g., ca. $60 \mathrm{~min}$ for strain $\mathrm{C} 7$ (14) and 155 min for strain PW8 (10).

The phospholipid pattern (diphosphatidyl glycerol, phosphatidyl glycerol, phosphatidyl inositol, phosphatidylinositol mannoside, and seldom more than traces of phosphatidyl ethanolamine [43] is characteristic of corynebacteria 
related to the type species, $C$. diphtheriae, and the pattern in conjunction with the presence of corynomycolic acids, has been designated phospholipid fatty acid type 4 by Lechevalier et al. (48).

From the foregoing it is clear that $M$. flavum strain 8 is a corynebacterium. In Table 2 its distinctive biochemical properties are presented in conjunction with those of $C$. diphtheriae, $C$. pseudodiphtheriticum, C. renale, and C.xerosis. We propose that Microbacterium flavum be placed in the genus Corynebacterium. However, because the name Corynebacterium flavum Kisskalt and Berend 1918 is a legitimate and validly published name of a different organism (19), a different specific epithet must be chosen (46) for $M$. flavum when transferred to Corynebacterium. Thus we have selected the specific epithet "flavescens." The nomenclature and an amended description of this organism follow.

Nomenclature. Corynebacterium flavescens nom. nov. Synonyms: Microbacterium flavum Orla-Jensen 1919; Mycobacterium flavum (OrlaJensen) Jensen 1934.

Generic properties. Nonmotile, nonsporeforming, gram-positive to gram-variable, nonacid-fast (Ziehl-Neelsen stain), pleomorphic, rod-shaped bacteria which exhibit moderately tapered ends (cells from actively growing cultures appear as doublets with tapered ends). When grown on phosphate-rich medium, cells contain metachromatic granules which can be revealed by staining with alkaline methylene blue or toluidine blue. Metabolism: aerobic to facultatively anaerobic; produces catalase; fails to ferment lactose or xylose. The cell wall is characterized $(41,63,65,74)$ by peptidoglycan of a directly cross-linked meso-diaminopimelic acid (A1 $\gamma$ of Schleifer and Kandler [66]); the major cell wall sugars are arabinose, galactose, and mannose; the major cell wall lipids are corynomycolic acids, unbranched and branched, ranging from 32 to 36 carbons, and monocorynomycolates of trehalose; phospholipids include diphosphatidyl glycerol, phosphatidyl glycerol, phosphatidyl inositol, phosphatidylinositol mannoside, and traces of phosphatidyl ethanolamine.

Specific properties. On Loeffler medium inspissated serum slants, growth appears yellow. Colonies on BHI agar are smooth, butyrous, and cream colored. Pellets of bacteria centrifuged from broth are yellow. Two-day-old colonies on tellurite agar are grayish black; 10-day-old, well isolated colonies are characterized by leached (grayish-white) centers. A yeasty odor is associated with growth on galactose agar plates. Small amounts of iodinophilic starch are produced from glucose 1-phosphate. Growth does not oc- cur on minimal media, e.g., Sauton medium. Luxuriant growth is produced in a basal medium plus glutamic acid, isoleucine, methionine, proline, $p$-aminobenzoic acid, biotin, nicotinic acid, pantothenic acid, and thiamine. Mean generation time in defined medium, $160 \mathrm{~min}$; in BHI medium, $87 \mathrm{~min}$. Characteristic biochemical reactions include: failure to deaminate pyrazinamide, to produce an alkaline phosphatase, to hydrolyze sodium hippurate, to reduce nitrates, to produce $\mathrm{H}_{2} \mathrm{~S}$, to hydrolyze gelatin, to curdle or hydrolyze milk, to produce ornithine and lysine decarboxylases, to hydrolyze polyoxyethylene sorbitan monooleate or urea and the capacity to ferment glucose, fructose, galactose, mannose, and mannitol (but not arabinose, adonitol, dulcitol, dextrin, glycerin, inositol, inulin, maltose, melibiose, raffinose, rhamnose, salicin, sorbitol, starch, sucrose, or trehalose), to hydrolyze sorbitan palmitate, sorbitan stearate, and sorbitan laurate, to produce acetoin, and to yield a positive methyl red test. The major fatty esters produced are 15:0 branched, 16:0, and 18: 1. The G+C content is $58.3 \mathrm{~mol} \%$. The DNA shows $64 \%$ homology with the DNA of $C$. diph. theriae strain PW8.

Type strain. Strain 8 of Orla-Jensen (= ATCC $10340=$ NC1B 8707) is here designated as the type strain of $C$. flavescens. It is one of the strains on which Orla-Jensen (57) based his original description of this organism (as Microbacterium flavum) and it possesses the characters given in the original description. The characters given above for the species are also the characters of strain 8 .

\section{ACKNOWLEDGMENTS}

We are much indebted to Pasquale F. Bartell, who kindly made available his laboratory and equipment for the DNA studies reported in this paper. We are grateful to ICI United States, Incorporated (formerly The Atlas Chemical Co.), Wilmington, Del., for generously supplying us with Tween 20,40 , 60 , and 80 .

\section{REPRINT REQUESTS}

Address reprint requests to: Dr. L. Barksdale, Department of Microbiology, New York University Medical Center, New York, NY 10016.

\section{LITERATURE CITED}

1. Abd-el-Malek, Y., and T. Gibson. 1952. Studies in the bacteriology of milk. III. The corynebacteria of milk. J. Dairy Sci. 19:153-159.

2. Alshamaony, L., M. Goodfellow, D. E. Minnikin, G. H. Bowden, and J. M. Hardie. 1977. Fatty and mycolic acid composition of Bacterionema matruchotii and related organisms. J. Gen. Microbiol. 98:205-213.

3. Arden, S. B. 1970. Comparative studies of Corynebacterium diphtheriae, $C$. ovis, $C$. ulcerans and related species. University Microfilms International, Ann Arbor, Mich.

4. Arden, S. B., and L. Barksdale. 1974. Glucose-1-phosphate-induced accumulation of intracellular starch: a 
distinguishing feature of certan corynebacteria. Int. J. Syst. Bacteriol. 24:139-141.

5. Arden, S. B., and L. Barksdale. 1976. Nitrate reductase activities in lysogenic and nonlysogenic strains of Corynebacterium diphtheriae and related species. Int. J. Syst. Bacteriol. 26:66-73.

6. Asselineau, J. 1966. The bacterial lipids. Hermann, Paris.

7. Azuma, I., Y. Yamamura, and A. Misaki. 1969. Isolation and characterization of arabinose mycolate from firmly bound lipids of mycobacteria. J. Bacteriol. 98: 331-333.

8. Baess, I. 1974. Isolation and purification of deoxyribonucleic acid from mycobacteria. Acta Pathol. Microbiol. Scand. 82:780-784.

9. Barer, G. 1946. The rapid detection of gelatin liquefying organisms. Mon. Bull. Minist. Health Public Health Lab. Serv. 5:28-29.

10. Barksdale, L. 1959. Symposium on the biology of cells modified by viruses or antigens. I. Lysogenic conversions in bacteria. Bacteriol. Rev. 23:202-212.

11. Barksdale, L. 1970. Corynebacterium diphtheriae and its relatives. Bacteriol. Rev. 34:378-422.

12. Barksdale, L., and K.-S. Kim. 1977. Mycobacterium. Bacteriol. Rev. 41:217-372.

13. Barksdale, W. L., K. Li, C. S. Cummins, and H. Harris. 1957. The mutation of Corynebacterium pyogenes to Corynebacterium haemolyticum J. Gen. Microbiol. 16:749-758.

14. Barksdale, W. L., and A. M. Pappenheimer, Jr. 1954. Phage-host relationships in nontoxigenic and toxigenic diphtheria bacilli. J. Bacteriol. 67:220-232.

15. Bousfield, I. J. 1972. A taxonomic study of some coryneform bacteria. J. Gen. Microbiol. 71:441-455.

16. Bradley, S. G., and M. Mordarski. 1976. Association of polydeoxyribonucleotides of deoxyribonucleic acids from nocardioform bacteria, p. 310-336. In M. Goodfellow, G. H. Brownell, and J. A. Serrano (ed.), Biology of the nocardiae. Academic Press Inc., New York.

17. Brennan, P. J., and D. P. Lehane. 1971. The phospholipids of corynebacteria. Lipids 6:401-409.

18. Buchanan, R. E., and N. E. Gibbons (ed.). 1974. Bergey's manual of determinative bacteriology, 8 th ed. The Williams \& Wilkins Co, Baltimore.

19. Buchanan, R. E., J. G. Holt, and E. F. Lessel, Jr. (ed.). 1966. Index bergeyana. The Williams \& Wilkins Co., Baltimore.

20. Collins-Thompson, D. L., T. Sorhaug, L. D. Witter, and Z. J. Ordal. 1972. Taxonomic consideration of Microbacterium lacticum, Microbacterium flavum and Microbacterium thermosphactum. Int. J. Syst. Bacteriol. 22:65-72.

21. Cummins, C. S. 1965. Chemical and antigenic studies on cell walls of mycobacteria, corynebacteria and nocardias. Am. Rev. Respir. Dis. 92:63-72.

22. Cummins, C. S., and H. Harris. 1956. The chemical compositon of the cell in some gram-positive bacteria and its possible value as a taxonomic character. J. Gen. Microbiol. 14:583-600.

23. DeLey, J., H. Cattoir, and A. Reynaerts. 1970. The quantitative measurement of DNA hybridization from renaturation rates. Eur. J. Biochem. 12:133-142

24. Dittmer, J. C. F., and R. L. Lester. 1964. A simple specific spray for the detection of phospholipids on thin layer chromatograms. J. Lipid Res. 5:126-127.

25. Drew, R. M., and J. H. Mueller. 1951. A chemically defined medium suitable for the production of high titer diphtherial toxin. J. Bacteriol. 62:549-559.

26. Edwards, P. R., and W. H. Ewing. 1972. Identification of Enterobacteriaceae, 3rd ed. Burgess Publishing Co., Minneapolis.

27. Frazier, W. C. 1926. A method for the detection of changes in gelatin due to bacteria. J. Infect. Dis. 39: 302-309.
28. Friedberg, I., and G. Avigad. 1968. Structures containing polyphosphate in Micrococcus lysodeikticus. J. Bacteriol. 96:544-553.

29. Furness, G., and A. T. Evangelista. 1976. Infection of nonspecific urethritis patient and his consort with a pathogenic species of non-specific urethritis corynebacteria, Corynebacterium genitalium, n. sp. Invest. Urol. 14:202-205.

30. Goodfellow, M., M. D. Collins, and D. E. Minnikin. 1976. Thin-layer chromatographic analysis of mycolic acid and other long-chain components in whole-organism methanolysates of coryneform and related taxa. J. Gen. Microbiol. 96:351-358.

31. Harrington, B. J. 1966. A numerical taxonomic study of some corynebacteria and related organisms. J. Gen. Microbiol. 45:31-40.

32. Hentrich, F., B. Menge, and K. G. Lickfeld. 1977. Studies on the fine structure of Corynebacterium diphtheriae granules. Zentralbl. Bakteriol. Parasitenkd. Infekstionskr. Hyg. Abt. 1 Orig. Reihe A 239:240-251.

33. Hirai, K., S. Shimakura, and R. Yanagawa. 1969. Minimum medium for Corynebacterium renale and filamentous growth due to deficiency or excess of inorganic ions. Jpn. J. Vet. Sci. 31:149-159.

34. Hirai, K., and R. Yanagawa. 1967. Nutritional requirements of Corynebacterium renale. Jpn. J. Vet. Res. 15: 121-134.

35. Holmes, R. K., and L. Barksdale. 1969. Genetic analysis of tox $x^{+}$and tox $x^{-}$bacteriophages of Corynebacterium diphtheriae. J. Virol. 3:586-598.

36. Holmes, R. K., and L. Barksdale. 1970. Comparative studies with tox $x^{+}$and tox $x^{-}$corynebacteriophages. J. Virol. 5:783-794.

37. Jayne-Williams, D. J., and T. M. Skerman. 1966. Comparative studies on coryneform bacteria from milk and dairy sources. J. Appl. Bacteriol. 29:72-92.

38. Jensen, H. L. 1934. Studies on saprophytic mycobacteria and corynebacteria. Proc. Linn. Soc. N.S.W. 59:19-61.

39. Kanetsuna, F., and G. San Blas. 1970. Chemical analysis of a mycolic acid-arabinogalactan-mucopeptide complex of mycobacterial cell wall. Biochim. Biophys. Acta 208:434-443.

40. Keddie, R. M., and G. L. Cure. 1977. The cell wall composition and distribution of free mycolic acids in named strains of coryneform bacteria and in isolates from various natural sources. J. Appl. Bacteriol. 42: 229-252.

41. Keddie, R. M., B. G. S. Leask, and J. M. Grainger. 1966. A comparison of coryneform bacteria from soil and herbage: cell wall composition and nutrition. J. Appl. Bacteriol. 29:17-43.

42. Kitaura, T., T. Hirano, S. Inui, S. Kotani, M. Higashigawa, and T. Tsuchitani. 1959. Chemical composition of the cell wall of Corynebacterium diphtheriae. Nara Igaku Zasshi 10:45-48. (in Japanese)

43. Komura, I., K. Yamada, S. I. Otsuka, and K. Komagata. 1975. Taxonomic significance of phospholipids in coryneform and nocardioform bacteria. J. Gen. Appl. Microbiol. 21:251-261.

44. Lampidis, T., and L. Barksdale. 1971. Park-Williams number 8 strain of Corynebacterium diphtheriae. J. Bacteriol. 105:77-85.

45. Laneélle, M.-A., and J. Asselineau. 1977. Glycolipids of Brevibacterium vitarumen. Biochim. Biophys. Acta 486:205-208.

46. Lapage, S. P., P. H. A. Sneath, E. F. Lessel, V. B. D. Skerman, H. P. R. Seeliger, and W. A. Clark (ed.). 1975. International code of nomenclature of bacteria and statutes of the International Committee on Systematic Bacteriology and statutes of the Bacteriology Section of the International Association of Microbiological Societies. American Society for Microbiology, Washington, D.C. 
47. Lechevalier, M. P. 1976. Lipids in bacterial taxonomy; a taxonomist's view. Crit. Rev. Microbiol. 5: 109-210.

48. Lechevalier, M. P., C. deBievre, and H. Lechevalier. 1977. Chemotaxonomy of aerobic actinomycetes: phospholipid composition. Biochem. Syst. Ecol. 5:249-260.

49. Levinson, S. A., and R. P. MacFate. 1956. Clinical laboratory diagnosis, 5 th ed. Lea \& Febiger, Philadelphia.

50. MacFaddin, J. F. 1976. Biochemical tests for identification of medical bacteria. The Williams \& Wilkins Co. Baltimore.

51. Mandel, M., L. Igambi, J. Bergendahl, M. L. Dodson, Jr., and E. Scheltgen. 1970. Correlation of melting temperature and cesium chloride buoyant density of bacterial deoxyribonucleic acid. J. Bacteriol. 101:333338.

52. Marmur, J. 1961. A procedure for the isolation of deoxyribonucleic acid from micro-organisms. J. Mol. Biol. 3: 208-218.

53. Maximescu, P., and I. Nicoara. 1964. Modificarea probei cistinazei, folosita in diagnosticul bacteriologic al difteriei. Microbiol. Parazitol. Epidemiol. 9:551-553.

54. Mizuguchi, Y., and T. Tokunaga. 1970. Method for isolation of deoxyribonucleic acid from mycobacteria. J. Bacteriol. 104:1020-1021.

55. Moore, M. S., and E. I. Parsons. 1958. A study of a modified 'Tinsdale's medium for the primary isolation of Corynebacterium diphtheriae. J. Infect. Dis. 102:8893.

56. Mueller, J. H., and P. A. Miller. 1941. Production of diphtheria toxin of high potency $(100 \mathrm{Lf})$ on a reproducible medium. J. Immunol. 40:21-32.

57. Orla-Jensen, S. 1919. The lactic acid bacteria. A. F. Host \& Son, Copenhagen.

58. Park, W. H., and A. W. Williams. 1896. The production of diphtheria toxin. J. Exp. Med. 1:164-185.

59. Pisu, I. 1940. Nuovo metodo di differenziazione culturale del B. difterico dai B. pseudodifterici: azione sulla cistina con produzione di $\mathrm{H}_{2} \mathrm{~S}$. Diagn. Tec. Lab. 10:643655.

60. Pudles, J., and E. Lederer. 1953. Sur la constitution chimique d'un acide mycolique insaturé isolé du bacille diphterique (Corynebacterium diphtheriae). Biochim. Biophys. Acta 11:163-164.

61. Pudles, J., and E. Lederer. 1954. Sur l'isolement et la constitution chimique de l'acide coryno-mycolénique et de deux cétones des lipides du bacille diphterique. Bull. Soc. Chim. Biol. 36:759-777.

62. Robinson, K. 1966. Some observations on the taxonomy of the genus Microbacterium. I. Cultural and physiological reactions and heat resistance. J. Appl. Bacteriol.
29:607-615.

63. Robinson, K. 1966. Some observations on the taxonomy of the genus Microbacterium. II. Cell wall analysis, gel electrophoresis and serology. J. Appl. Bacteriol. 29:616624.

64. Rouser, G., G. Kritchevsky, and A. Yamamoto. 1967. Column chromatographic and associated precedures for separation and determination of phosphotides and glycolipids, p. 99-162. In G. V. Marinetti (ed.), Lipid chromatographic analysis, vol. 1. Marcel Dekker, New York.

65. Schleifer, K. H. 1970. Die Mureintypen in der Gattung Microbacterium. Arch. Mikrobiol. 71:271-282.

66. Schleifer, K. H., and O. Kandler. 1972. Peptidoglycan types of bacterial cell walls and their taxonomic implications. Bacteriol. Rev. 36:407-477.

67. Skerman, T. M., and D. J. Jayne-Williams. 1966. Nutrition of coryneform bacteria from milk and dairy sources. J. Appl. Bacteriol. 29:167-178.

68. Sweeley, C. C., R. Bentley, M. Makita, and W. W. Wells. 1963. Gas-liquid chromatography of trimethylsilyl derivatives of sugars and related substances. J. Am. Chem. Soc. 85:2497-2507.

69. Tinsdale, G. F. W. 1947. New medium for isolation and identification of $C$. diphtheriae based on production of H.2S. J. Pathol. Bacteriol. 59:461-466.

70. Vestal, A. L. 1975. Procedures for the isolation and identification of mycobacteria. U.S. Department of Health, Education and Welfare publication no. (CDC) 75-8230. U.S. Government Printing Office, Washington, D.C.

71. Wayne, L. G. 1974. Simple pyrazinamidase and urease tests for routine identification of mycobacteria. Am. Rev. Respir. Dis. 109:147-151.

72. Wayne, L. G., J. R. Doubek, and R. L. Russell. 1964. Classification and identification of mycobacteria. I. Tests employing Tween 80 as substrate. Am. Rev. Respir. Dis. 90:588-597.

73. Wittern, A. 1933. Beitrage zur kenntnis der "Mikrobakterien" Orla-Jensen. Zentralbl. Bakteriol. Parasitenkd. Infektionskr. Hyg. Abt. 2 87:412-446.

74. Yamada, K., and K. Komagata. 1970. Taxonomic studies on coryneform bacteria. II. Principle amino acids in the cell wall and their taxonomic significance. J. Gen. Appl. Microbiol. 16:103-113.

75. Yamada, K., and K. Komagata. 1970. Taxonomic studies on coryneform bacteria. III. DNA base compositon of coryneform bacteria. J. Gen. Appl. Microbiol. 16: 215-224.

76. Yanagawa, R., and E. Honda. 1978. Corynebacterium pilosum and Corynebacterium cystitidis, two new species from cows. Int. J. Syst. Bacteriol. 28:209-216. 